\title{
Adsorption Kinetics for the Removal of Hazardous Dye Congo Red by Biowaste Materials as Adsorbents
}

\author{
Sumanjit Kaur, Seema Rani, and Rakesh Kumar Mahajan \\ Department of Chemistry, Guru Nanak Dev University, Amritsar 143005, India \\ Correspondence should be addressed to Sumanjit Kaur; sumangndu@yahoo.co.in
}

Received 7 June 2012; Revised 26 June 2012; Accepted 28 June 2012

Academic Editor: Arminda M. Alves

Copyright (C) 2013 Sumanjit Kaur et al. This is an open access article distributed under the Creative Commons Attribution License, which permits unrestricted use, distribution, and reproduction in any medium, provided the original work is properly cited.

\begin{abstract}
The present work aims to investigate the removal of dye congo red from aqueous solutions by two low-cost biowaste adsorbents such as ground nut shells charcoal (GNC) and eichhornia charcoal (EC) under various experimental conditions. The effect of contact time, ionic strength, temperature, $\mathrm{pH}$, dye concentration, and adsorbent dose on the removal of dye was studied. The kinetic experimental data were fitted to pseudo-first order, pseudo-second order, intraparticle diffusion, Elovich model, and Bangham's model. Results imply that adsorption of congo red on these adsorbents nicely followed the second order kinetic model and maximum adsorption capacity was found to be 117.6 and $56.8 \mathrm{mg} \mathrm{g}^{-1}$ for GNC and EC at $318 \mathrm{~K}$, however it increases with increase in temperature for both adsorbents. Equilibrium isotherms were analyzed by Langmuir, Freundlich, Temkin, Dubinin and Radushkevich, and Generalized Isotherms. Freundlich isotherm described the isotherm data with high-correlation coefficients. The results of the present study substantiate that biowaste material GNC and EC are promising adsorbents for the removal of the dye congo red.
\end{abstract}

\section{Introduction}

Dye, a constituent that is widely used in textile, paper, plastic, food, and cosmetic industries is an easily recognized pollutant [1]. Decolourizing of textile and manufacturing waste water is currently a major problem for environmental managers [2]. Dyes may significantly affect photosynthetic activity in aquatic life due to the presence of aromatics, metals, chlorides, and so forth, in them [3]. Many of the dyes used in the industries are stable to light and oxidation, as well as resistant to aerobic digestion [4]. However, dyes usually have a synthetic origin and complex aromatic molecular structure which makes them more stable so they are not biodegradable and photodegradable, it brings some difficulties for the treatment of these pollutants [5]. Congo red (CR) (1-napthalenesulfonic acid, 3,3'-(4,4'-biphenylene bis (azo)) bis (4-amino-) disodium salt) is a benzidine-based anionic disazo dye, this dye is known to metabolize to benzidine, a known human carcinogen [6].

Physicochemical processes are generally used to treat dyes laden waste water. These processes include flocculation, electro flotation, precipitation, electrokinetic coagulation, ion exchange, membrane filtration, electrochemical destruction, irradiation, and ozonation. However, all these processes are costly and cannot be used by small industries to treat wide range of dye waste water [7]. The adsorption process provides an attractive alternative for the treatment of contaminated waters, especially if the sorbent is inexpensive and does not require an additional pretreatment step before its application [8]. Adsorption is known to be a better technique, which has great importance due to the ease of operation and comparable low cost of application in decoloration process [9].

Activated carbon is the most widely used adsorbent with great success due to its large surface area, microporous structure, and high-adsorption capacity. However, its use is limited because of its high cost. This has led to search for cheaper substitutes [10]. Investigators have studied the feasibility of using low-cost substances, such as waste apricot [11], coconut shell [12], dairy sludge [13], bamboo grass treated with concentrated sulfuric acid [14], peat [15], orange peels [16], pea nut hulls [17], rice husk [18], ground nut shells charcoal and bagasse [19], bamboo [20], jack fruit peels [21], pistachio nut shells [22], and date stone and palm tree waste [23] as adsorbents for the removal of dyes and heavy 
metals from waste water. The purpose of present work is to study the mechanism of adsorption of congo red on ground nut shells charcoal (GNC) and eichhornia charcoal (EC). Eichhornia crassipes is one of the worst weeds in the world. Its vigorous grower is known to double their population within two weeks. Large, dense Eichhornia crassipes mat can degrade water quality and can choke water ways. The kinetics, equilibrium, and thermodynamic parameters are studied to describe the rate and mechanism of adsorption to determine the factor controlling the rate of adsorption and to find out the possibility of using these biomaterials as low-cost adsorbents for the removal of dye CR. The effect of solution concentration, adsorbent dose, ionic strength, temperature, and $\mathrm{pH}$ on $\mathrm{CR}$ adsorption has been evaluated.

\section{Experimental}

\subsection{Materials and Methods}

2.1.1. Adsorbents. Groundnut shells was used as an adsorbent, was collectively obtained from the local shop, Amritsar (India) washed with tap water and finally with double distilled water to remove the suspended impurities, dust, and soil and then dried in oven. Eichhornia was collected from pond at Ram Tirath Road, Amritsar. Charcoal of both the materials was prepared in a very economical way, that is, by burning in the absence of free excess of air and then charcoal was sieved through sieves to remove course particles.

2.1.2. Dye Solution Preparation. The dye congo red (C.I name $=$ Direct Red 28, C.I No. $=22120$, Chemical formula $=$ $\mathrm{C}_{32} \mathrm{H}_{22} \mathrm{~N}_{6} \mathrm{O}_{6} \mathrm{~S}_{2} \mathrm{Na}_{2}$, Formula weight $\left.=696.65\right)$ is supplied by S.D fine Chemicals, Mumbai, India, was used as such without further purification. An accurately weighed quantity of dye was dissolved in double distilled water to prepare the stock solution $\left(65 \mathrm{mg} \mathrm{L}^{-1}\right)$. Serial dilutions were made by diluting it with double distilled water.

2.1.3. Adsorption Experiments. Adsorption experiments were carried out by agitating $100 \mathrm{mg}$ of adsorbent with $100 \mathrm{~mL}$ of dye solution, of the desired concentration and $\mathrm{pH}$, at different temperatures $(308,313$, and $318 \mathrm{~K})$ in a thermostated metrex water bath shaker with a shaking of $120 \mathrm{rpm}$. The samples were withdrawn from the shaker at predetermined time intervals and dye solutions were separated from the adsorbent using whatman filter paper. The absorbance of supernatant solution was measured spectrophotometrically by monitoring the absorbance at $497 \mathrm{~nm}$ using a UV-vis spectrophotometer (1800, Shimadzu, Japan). Effect of $\mathrm{pH}$ was studied by adjusting the $\mathrm{pH}$ of dye solutions $(2.0,4.0,6.0,8.0,10.0$, and 12.0) using $0.1 \mathrm{~N} \mathrm{HCl}$ and $0.1 \mathrm{~N} \mathrm{NaOH}$ solutions. Batch equilibrium adsorption experiments were carried out by shaking $100 \mathrm{~mL}$ solution of various dye concentrations at $\mathrm{pH} 7.0$ with $100 \mathrm{mg}$ of adsorbents at 308,313 , and $318 \mathrm{~K}$, respectively.
The amount of dye adsorbed by the adsorbent was calculated using the following equation:

$$
\% \text { Removal }=\frac{\mathrm{Co}-\mathrm{Ce}}{\mathrm{Co}} \times 100,
$$

where $\mathrm{Co}$ and $\mathrm{Ce}\left(\mathrm{mg} \mathrm{L}^{-1}\right)$ are the concentrations of dye before and after adsorption.

The $\mathrm{pH}$ of zero point charge $\left(\mathrm{pH}_{\mathrm{zpc}}\right)$ plays an important role in the adsorption process. The $\mathrm{pH}_{\mathrm{zpc}}$ of GNC and EC was determined by the method reported by Rivera-Utrilla et al. 2001 [24]. For this purpose, $50 \mathrm{~mL}$ of a $0.01 \mathrm{M}$ sodium chloride $(\mathrm{NaCl})$ solution was placed in a $100 \mathrm{~mL}$ erlenmeyer flask. The $\mathrm{pH}$ was then adjusted to successive initial values between 2 and 12, by using either sodium hydroxide or hydrogen chloride $(0.1 \mathrm{~N})$, and $0.15 \mathrm{~g}$ of adsorbents (GNC or EC) were added to the solution. After a contact time of $24 \mathrm{~h}$, the final $\mathrm{pH}$ was measured and plotted against the initial $\mathrm{pH}$. The $\mathrm{pH}$ at which the curve crosses the line $\mathrm{pH}$ (final) $=\mathrm{pH}$ (initial) is taken as the $\mathrm{pH}_{\mathrm{zpc}}$.

\section{Results and Discussion}

3.1. FTIR Analysis. Measurements were carried out by means of a Varian Resolutions Pro-FTIR spectrometer. One centimeter diameter and constant-weight $\mathrm{KBr}$ pellets were prepared by mixing the samples with $\mathrm{KBr}$ at $1: 5$ ratio. The spectra were measured in the wave number range of $400-4000 \mathrm{~cm}^{-1}$. Figures 1 (a) and 1(b) shows the FTIR spectra of dye, adsorbent and dye loaded adsorbents. The band at $1366 \mathrm{~cm}^{-1}$ shows the asymmetric stretch of $\mathrm{S}=\mathrm{O}$. The peak values from $1350-1000 \mathrm{~cm}^{-1}$ may be due to $\mathrm{C}-\mathrm{N}$ bond of amine. The value $1615 \mathrm{~cm}^{-1}$ can be assigned to bending vibration of primary amine.

FTIR spectra of CR + GNC and CR + EC shows that peaks in the low frequency region $\left(<1000 \mathrm{~cm}^{-1}\right)$ which are present in the dye alone and are not observed in the dye loaded adsorbents because of the adsorption of dye CR on the adsorbent surface. Decreased intensity of sharp peaks concluded that dye has been functionalized by both the adsorbents.

3.2. Scanning Electronic Micrographic Studies (SEM). SEM is widely used to study the morphological features and surface characteristics of the adsorbent material. It also reveals the surface texture and porosity of adsorbent. Figure 2 shows that the surface of the adsorbent GNC and EC become smooth due to adsorption of congo red. It also plays an important role in determining the surface availability for the adsorption of dye on adsorbents.

3.3. X-Ray Diffraction Studies. The X-ray diffraction pattern was recorded in the scanning mode on an XRD 7000 (Shimadzu, Japan) analytical instrument operated at $40 \mathrm{KV}$ and a current of $30 \mathrm{~mA}$ with $\mathrm{Cu}-\mathrm{K} \alpha$ radiation $(\lambda=1.5406 \AA)$. $\mathrm{X}$-ray diffraction (XRD) technique is a powerful technique to analyze the crystalline and amorphous nature of the material under investigation. In crystalline material, well defined 

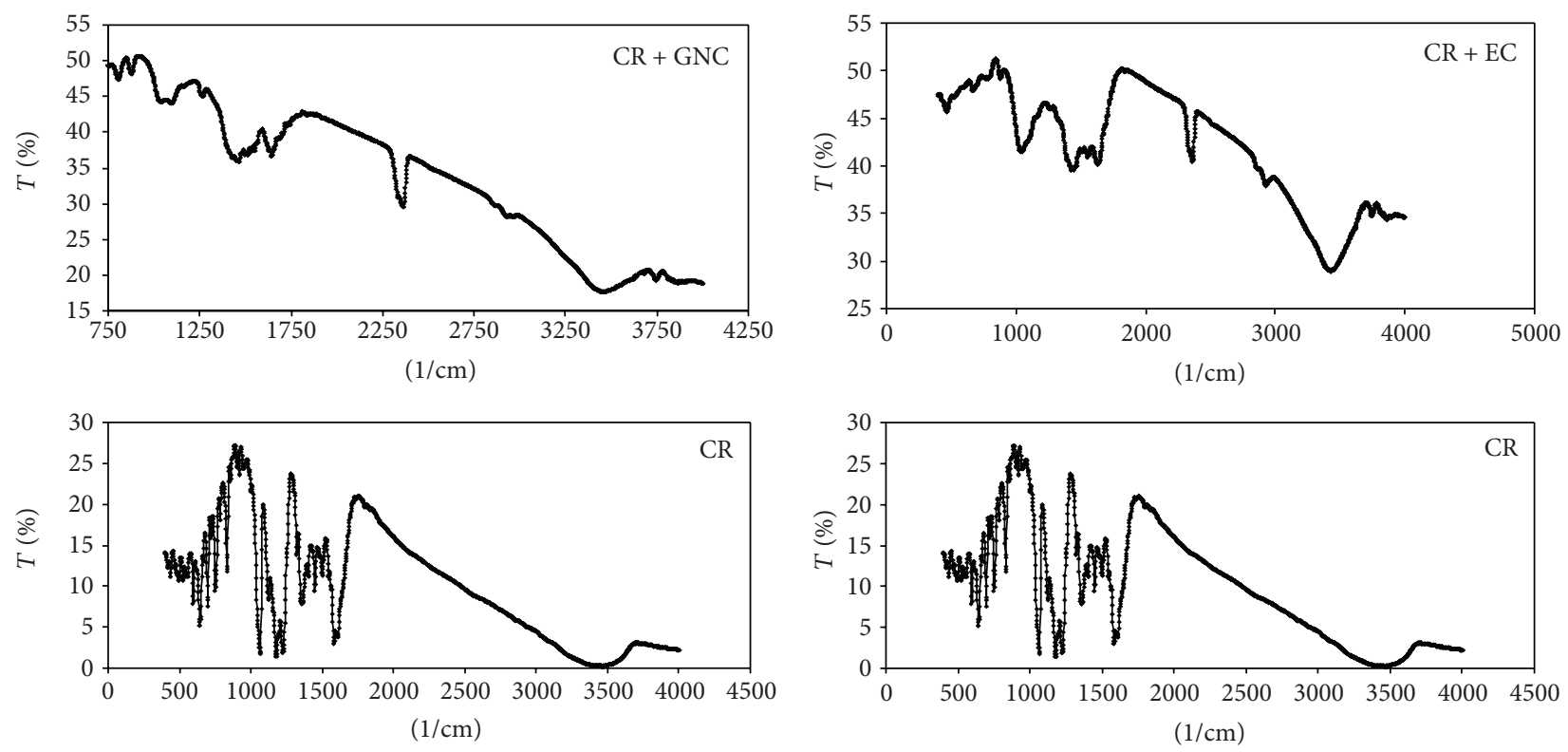

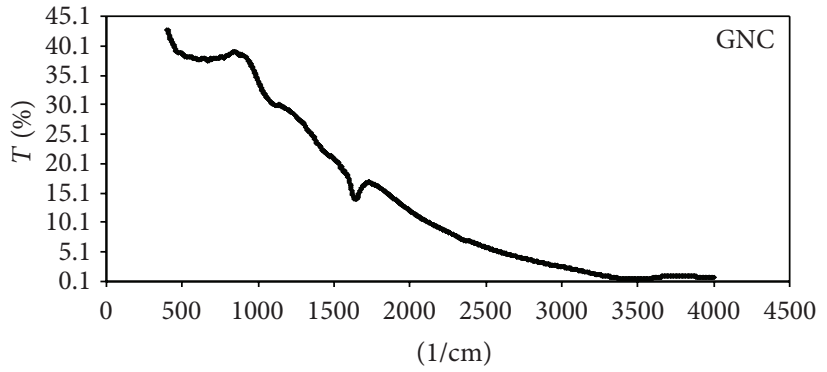

(a)

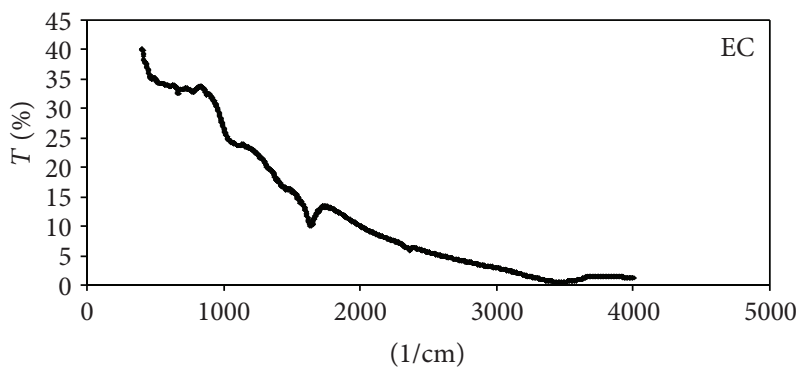

(b)

FIGURE 1: (a) FTIR spectra of GNC, CR, and dye loaded GNC. (b) FTIR spectra of EC, CR, and dye loaded EC.

peaks are observed whereas in noncrystalline or amorphous material shows broad peaks instead of sharp peaks. Figures 3(a) and 3(b) shows that well-defined peaks are observed for the adsorbent EC as compare to GNC which indicates that $\mathrm{EC}$ is more crystalline as compare to GNC. When the adsorbent get loaded by the dye molecules the crystalline nature of the dye changed into amorphous nature. It has been concluded that the dye molecules diffused into the microand macropores of the adsorbent molecules. XRD study reveals the change in crystallinity of the dye and adsorbent due to adsorption.

XRD crystallite size is calculated using Scherrer formula [25]

$$
D=K \frac{\lambda}{\beta} \cos \theta
$$

where $K$ is the shape factor, $\lambda$ is the $\mathrm{X}$-ray wavelength, $\beta$ is the line broadening at half the maximum intensity (FWHM) in radians, and $\theta$ is the Bragg angle. The dimensionless shape factor, $K$, has a typical value of about 0.9 , but varies with the actual shape of the crystallite. Peak width is inversely proportional to crystalline size, results show that as crystalline size get smaller, peak get broader. Peak intensity is usually weakest at large angle $2 \theta$. Particle size at maximum intensity was found to be 42.4 and $13.4 \mathrm{~nm}$ for EC and GNC, respectively. Similar method was adopted by Prema et al. 2011 [26] to calculate the average size of the particles.

3.4. Effect of Contact Time. Figure 4 illustrates the effect of contact time on the adsorption of dye CR at different temperatures using different adsorbents. It is indicated that uptake of the dye is rapid in the beginning and then it becomes constant. The adsorption curves are single, smooth, and continuous leading to saturation and indicate the possible monolayer coverage on the surface of adsorbents by the dye molecules [27]. The equilibrium time for $\mathrm{EC}$ is 90,60 , and 40 minutes and for GNC is 80,60 , and 30 minutes at 308,313 , and $318 \mathrm{~K}$, respectively.

3.5. Effect of $p H$. The percentage of dye adsorption at different $\mathrm{pH}$ is shown in Figure 5. The initial $\mathrm{pH}$ of dye solution plays an important role particularly on the adsorption capacity by influencing the chemistry of both dye molecule and adsorbents (GNC and EC) in aqueous solutions. The color of $\mathrm{CR}$ in aqueous solution is solid red at $\mathrm{pH}$ around 7. The color of CR changes to dark blue at acid $\mathrm{pH}$ and to red at alkaline $\mathrm{pH}(10-12)$, but this red color is slightly different from original red at the neutral $\mathrm{pH}$. CR exists as an anionic 


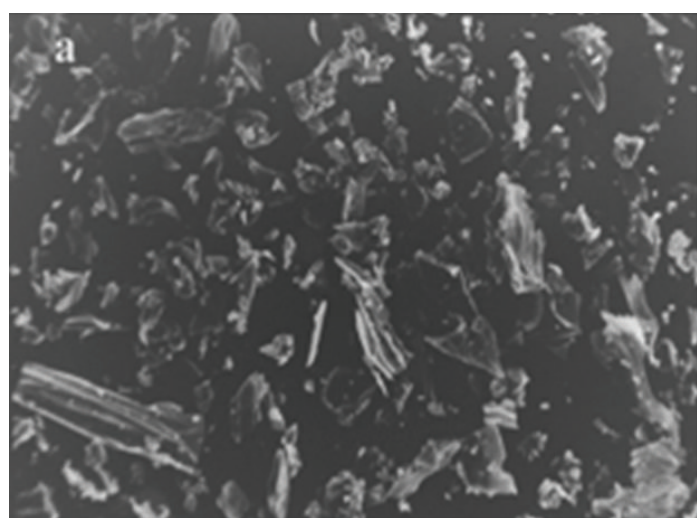

(a)

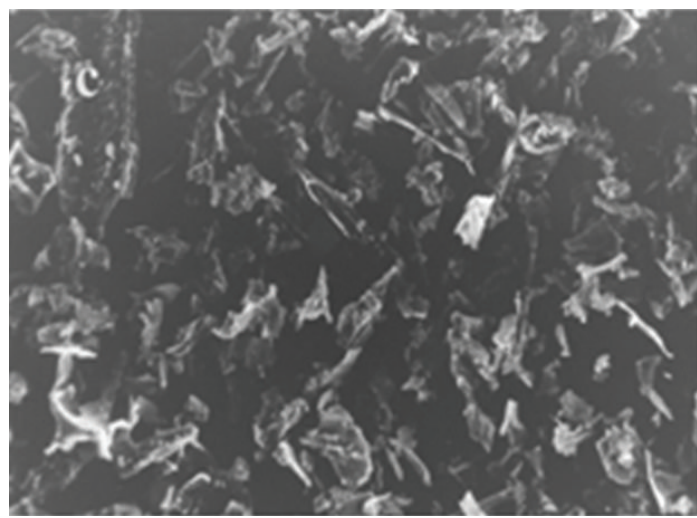

(c)

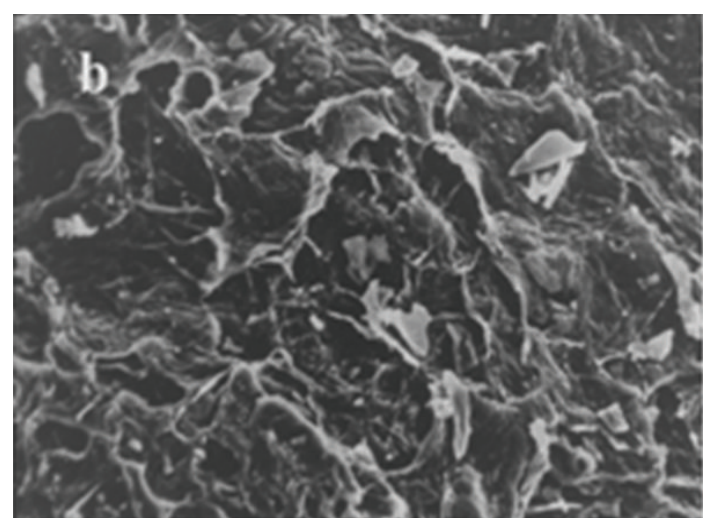

(b)

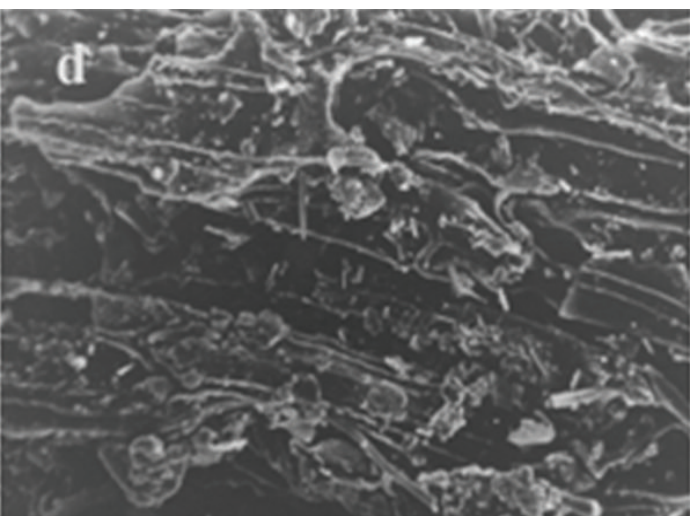

(d)

FIGURE 2: Scanning electron microscope (SEM) images of ground nut shell (GNC) (a) before adsorption, (b) after adsorption; Eichhornia charcoal (EC), (c) before adsorption, (d) after adsorption.

form at basic $\mathrm{pH}$ (sulfonate groups) and as a cationic form at acid $\mathrm{pH}$. The zero point charge $\left(\mathrm{pH}_{\mathrm{zpc}}\right)$ of GNC and EC was determined [24]. Adsorption of cation is favored at $\mathrm{pH}>$ $\mathrm{pH}_{\mathrm{zpc}}$, while the adsorption of anion is favored at $\mathrm{pH}<$ $\mathrm{pH}_{\mathrm{zpc}}$ [28]. The $\mathrm{pH}_{\mathrm{zpc}}$ value for GNC and $\mathrm{EC}$ was found to be 9.1 and 7.8, respectively. As illustrated in the Figure 5, when $\mathrm{pH}$ value of dye solution increased from 2 to 12 , the percentage of dye adsorption sharply reduced from 94 to $73 \%$ in case of GNC and 75 to $51 \%$ in case of EC. At pH 2.0 a significantly high-electrostatic attraction exists between the positively charged surface of the adsorbent and anionic dye. As the $\mathrm{pH}$ of the system increases, the number of negatively charged sites increases and the number of positively charged sites decreases. A negatively charged surface site on the adsorbent does not favor the adsorption of dye anions due to the electrostatic repulsion. Also, lower adsorption of CR at alkaline $\mathrm{pH}$ is due to the presence of excess $\mathrm{OH}^{-}$ions competing with the dye anions for the adsorption sites. Nevertheless, significant adsorption of anionic dye on the adsorbent still occurred above $\mathrm{pH}_{\mathrm{zpc}}$ due to the fact that a chemical interaction between the dye and GNC and EC, respectively. Similar results have been reported for the adsorption of CR on waste orange peel [29] and activated carbon [30].
3.6. Effect of Temperatures. The sorption experiments were reported at three temperatures ranging 308,313 , and $318 \mathrm{~K}$ for GNC and EC. Figure 4 shows that percentage colour removal increases with increase in temperature implying that high temperature favors for the removal of CR from aqueous solutions. Increase in temperature decreases the solubility of dye and hence adsorption increases. Increased adsorption may also be as a result of increase in the mobility of the large dye ion with temperature. An increasing number of molecules may acquire sufficient energy to undergo an interaction with active site at the surface [31]. Therefore increase in sorptive uptake of $\mathrm{CR}$ with increase in temperature may be partly attributed to chemisorptions.

3.7. Effect of Adsorbent Dose. The effect of adsorbent dose on the removal of congo red by GNC and EC at initial concentration $\left(\mathrm{Co}=65 \mathrm{mg} \mathrm{L}^{-1}\right)$ is illustrated in Figure 6. Results describe that $\mathrm{CR}$ removal increases upto a certain limit and then it remains almost constant. With increase in the adsorbent dose from 0.1 to $1.2 \mathrm{~g}$, dye uptake increases from $83-95 \%$ and $60-82 \%$ for GNC and EC, respectively. Increase in adsorption with adsorbent dosage can be attributed to increased adsorbent surface area and availability of more adsorption sites. 

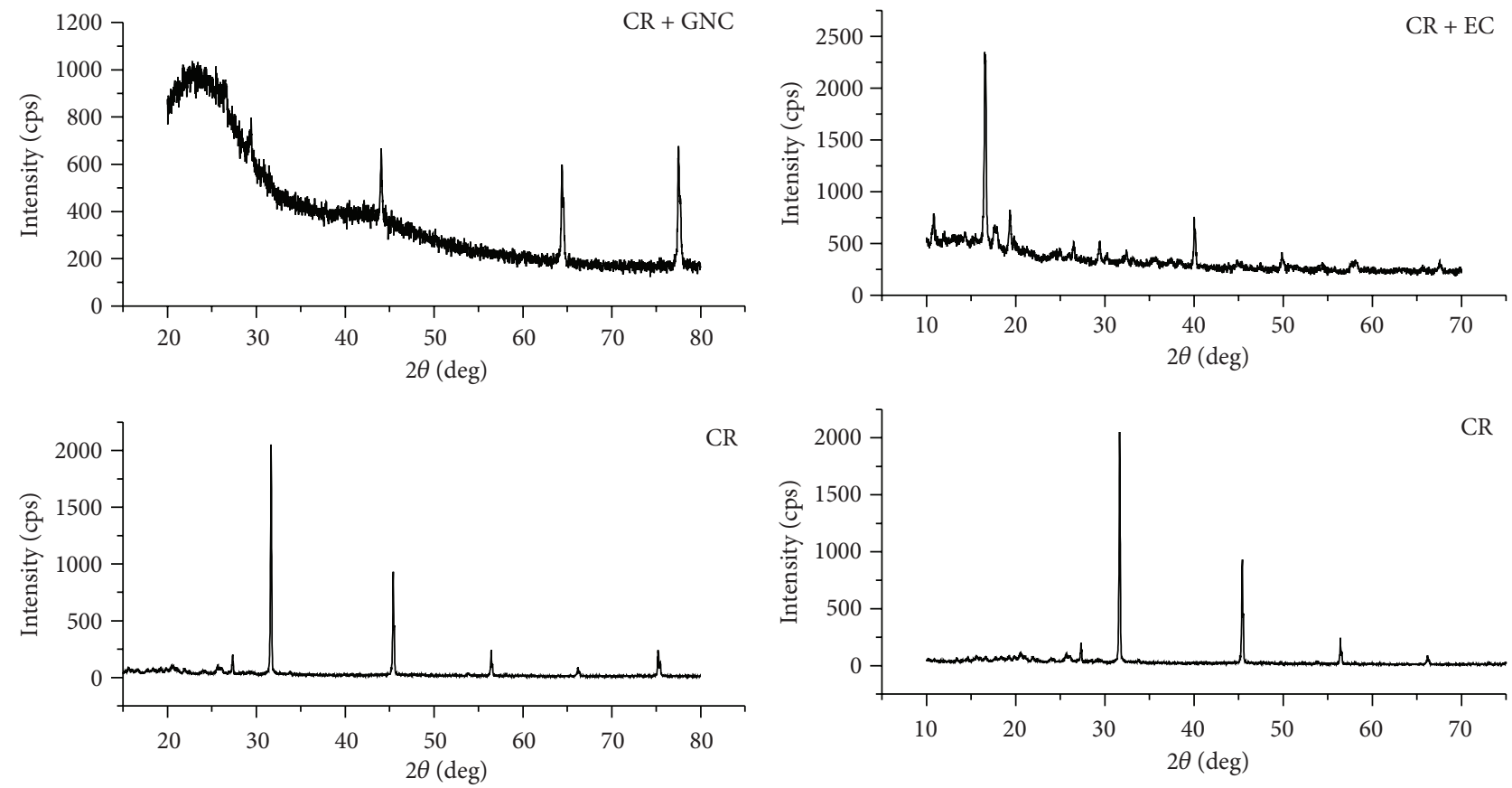

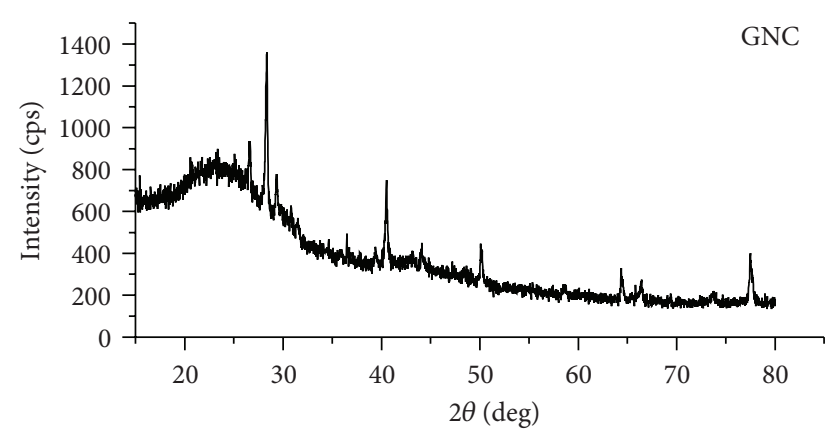

(a)

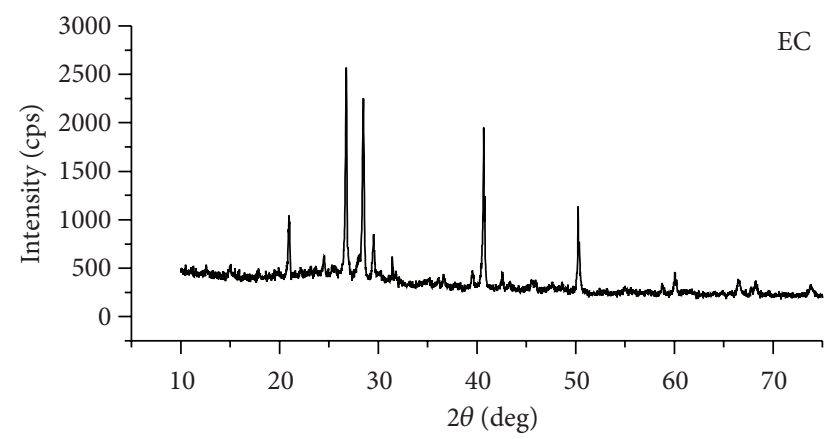

(b)

FIGURE 3: (a) XRD spectra of GNC, CR, and dye loaded GNC. (b) XRD spectra of EC, CR, and dye loaded EC.

3.8. Effect of Ionic Strength. Different concentrations of $\mathrm{KCl}$ and $\mathrm{NaCl}(0.01-0.05 \mathrm{M})$ were added to investigate the effect of ionic strength on adsorptive removal of CR. Figure 7 narrates that increase in ionic strength causes increase in the adsorption of congo red. Salt addition increases the aggregation of dye molecules and decreases the solubility. An increase in aggregation promotes the adsorption of dye molecules [32]. Another plausibility is that increase in ionic strength increases the positive charge of the adsorbent surface thus increases the electrostatic attraction between dye (CR) and adsorbent. Thus increase in ionic strength was found to have an increase in adsorption of CR.

3.9. Effect of Initial Concentration. The effect of initial concentration on the removal of CR by both the adsorbents is indicated in Figure 8. Experiment was done at constant adsorbent dose $1 \mathrm{~g} \mathrm{~L}^{-1}$. It is evident from the figure that percentage CR removal decreases with increase in CR concentration, however actual amount of the dye adsorbed $\left(q_{t}\right)$ is increased. This is due to increase in CR concentration, surface area, and active sites of the adsorbent were saturated and hence percentage removal decreases.

\subsection{Adsorption Kinetic Study}

3.10.1. Pseudo-First Order and Pseudo-Second Order Models. The pseudo-first-order equation is given as [33]

$$
\frac{d q_{t}}{d t}=k_{f}\left(q_{e}-q_{t}\right)
$$

where $q_{t}\left(\mathrm{mg} \mathrm{g}^{-1}\right)$ is the amount of dye adsorbed at time t. $q_{e}\left(\mathrm{mg} \mathrm{g}^{-1}\right)$ is the adsorption capacity at equilibrium, $k_{f}$ $\left(\mathrm{min}^{-1}\right)$ is the pseudo first order rate constant, and $t$ is the contact time (min). The integration of (3) with initial condition $\left(q_{t}=0\right.$ at $\left.t=0\right)$ leads to following equation:

$$
\log \left(q_{e}-q_{t}\right)=\log q_{e}-\frac{k_{f}}{2.303} t
$$




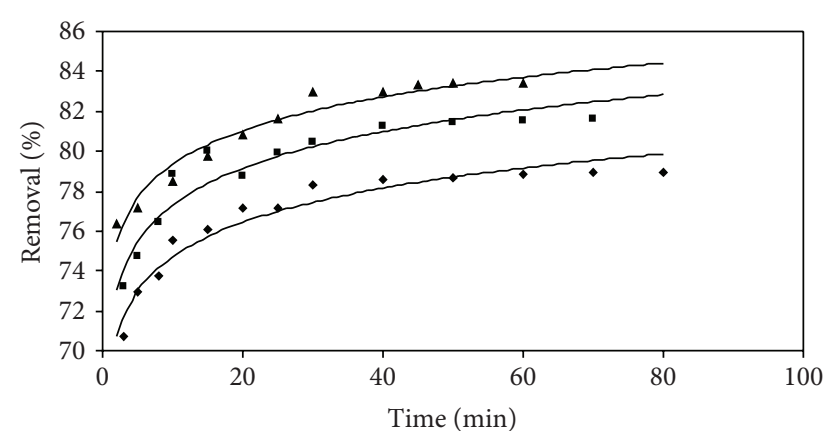

GNC

- $308 \mathrm{~K}$

- $313 \mathrm{~K}$

^ $318 \mathrm{~K}$

(a)

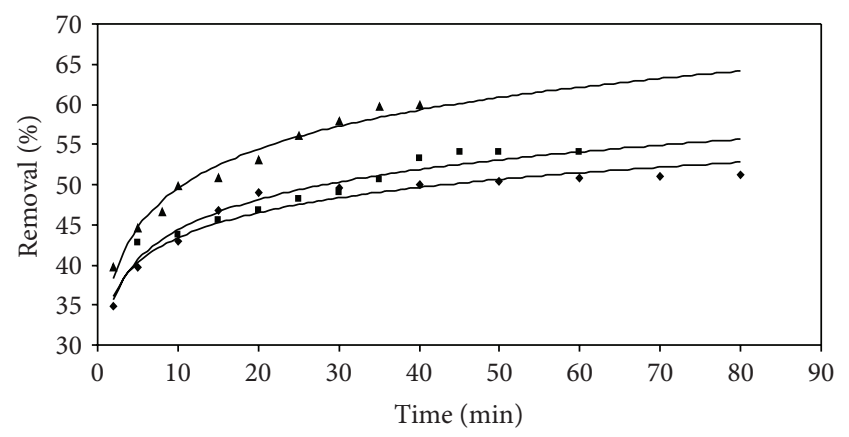

EC

- $308 \mathrm{~K}$

- $313 \mathrm{~K}$

- $318 \mathrm{~K}$

(b)

Figure 4: The effect of contact time on the adsorption of congo red by GNC and EC at different temperatures (sorbent dose $=1 \mathrm{~g} \mathrm{~L}^{-1}$, $\mathrm{Co}=65 \mathrm{mg} \mathrm{L}^{-1}, \mathrm{pH}=7.0$ ).

The values of $k_{f}$, calculated from the linear plots of $\log \left(q_{e}-q_{t}\right)$ versus $t$, for the adsorption of dye CR on both the adsorbents are given in Table 1. These plots are linear, however linearity of these curves does not necessarily assure first order mechanism [34] due mainly to the inherent disadvantage of correctly estimating equilibrium adsorption capacity $\left(q_{e}\right)$. The $q_{e}$ values obtained from Lagergren plots are different from the experimental $q_{e}$ values, therefore first order kinetic is less likely to explain the rate processes.

The pseudo-second order model is represented as [35]:

$$
\frac{d q_{t}}{d t}=k_{s}\left(q_{e}-q_{t}\right)^{2}
$$

where $k_{s}$ is the pseudo-second order rate constant $\left(\mathrm{g} \mathrm{mg}^{-1} \mathrm{~min}^{-1}\right)$. Integrating (5) and noting that $q_{t}=0$ at $t=0$, the following equation is obtained

$$
\frac{t}{q_{t}}=\frac{1}{k_{s} q_{e}^{2}}+\frac{1}{q_{e}} t
$$

The equilibrium adsorption capacity, $q_{e}$ is obtained from the slope and $k_{s}$ is obtained from the intercept of linear plot

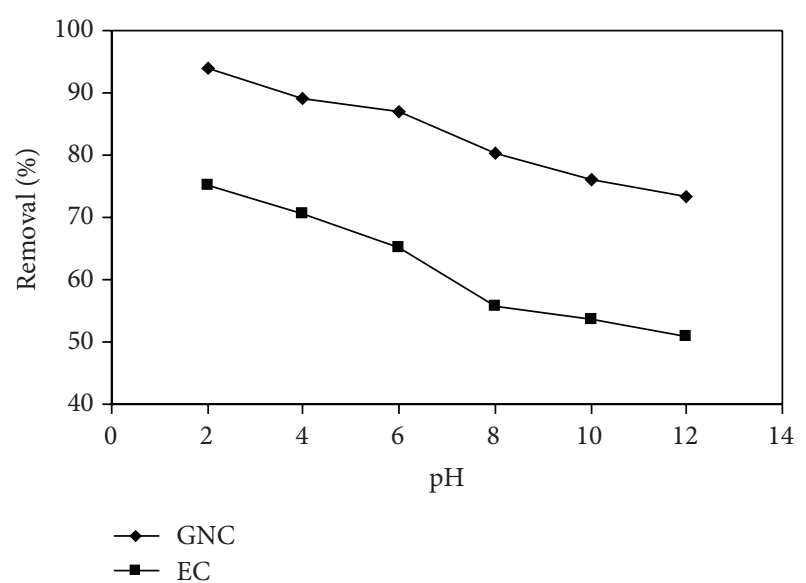

FIGURE 5: Effect of $\mathrm{pH}$ values on the adsorption of congo red by GNC and $\mathrm{EC}$ (sorbent dose $=1 \mathrm{~g} \mathrm{~L}^{-1}, \mathrm{Co}=65 \mathrm{mg} \mathrm{L}^{-1}$ ).

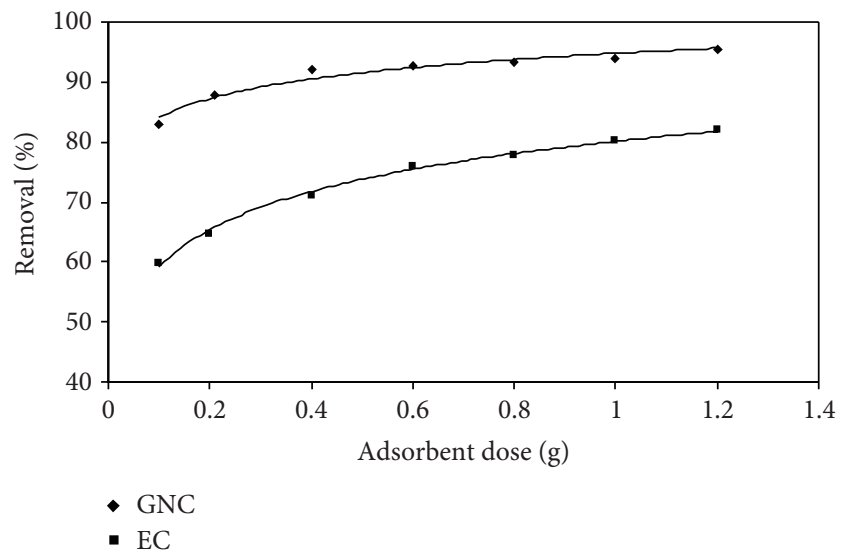

FIGURE 6: Effect of adsorbent dose on adsorption of congo red onto $\mathrm{GNC}$ and $\mathrm{EC}\left(\mathrm{Co}=65 \mathrm{mg} \mathrm{L}^{-1}, \mathrm{pH}=7.0\right)$.

of $t / q_{t}$ versus $t$. The values are furnished in Table 1. The $q_{e}$ experimental and the $q_{e}$ calculated values from the pseudo second-order kinetic model are very close to each other. The calculated correlation coefficients are also close to unity $\left(R^{2}=0.99\right)$ for pseudo-second order kinetic than that for the pseudo-first order kinetic model. Therefore, the sorption can be approximated more appropriately by pseudo-second order kinetic model than the first-order kinetic model for both the biosorbents.

3.10.2. Intraparticle Diffusion Study. An empirically found functional relationship common to most adsorption process is that the uptake varies almost proportionally with $t_{1 / 2}$, the Weber-Morris plot $\left(q_{t}\right.$ versus $\left.t_{1 / 2}\right)$, rather than with the contact time, $t[36]$ :

$$
q_{t}=k_{\mathrm{id}} t_{1 / 2}+C
$$

where $k_{\mathrm{id}}$ is the intraparticle diffusion rate constant. Values of the intercept $(C)$ gives an idea about the thickness of boundary layer, that is, larger the intercept the greater is the 
TABLE 1: Kinetic parameters for the adsorption of congo red by GNC and EC at different temperatures.

\begin{tabular}{|c|c|c|c|c|c|c|c|}
\hline \multirow{3}{*}{ Equations } & \multirow{3}{*}{ Parameters } & \multicolumn{6}{|c|}{ Adsorbents } \\
\hline & & & GNC & & & $\mathrm{EC}$ & \\
\hline & & $308 \mathrm{~K}$ & $313 \mathrm{~K}$ & $318 \mathrm{~K}$ & $308 \mathrm{~K}$ & $313 \mathrm{~K}$ & $318 \mathrm{~K}$ \\
\hline \multirow{4}{*}{ Pseudo-first order } & $q_{e} \exp \left(\mathrm{mg} \mathrm{g}^{-1}\right)$ & 51.30 & 53.02 & 54.20 & 35.85 & 37.98 & 41.38 \\
\hline & $q_{e} \mathrm{cal}\left(\mathrm{mg} \mathrm{g}^{-1}\right)$ & 6.33 & 6.09 & 7.69 & 17.01 & 13.25 & 12.99 \\
\hline & $k_{f}\left(\min ^{-1}\right)$ & 0.083 & 0.081 & 0.059 & 0.058 & 0.064 & 0.065 \\
\hline & $R^{2}$ & 0.98 & 0.99 & 0.97 & 0.99 & 0.88 & 0.98 \\
\hline \multirow{4}{*}{ Pseudo-second order } & $q_{e} \exp \left(\mathrm{mg} \mathrm{g}^{-1}\right)$ & 51.30 & 53.02 & 54.20 & 35.85 & 37.98 & 41.38 \\
\hline & $q_{e} \mathrm{cal}\left(\mathrm{mg} \mathrm{g}^{-1}\right)$ & 51.81 & 53.44 & 55.86 & 37.05 & 39.65 & 42.97 \\
\hline & $k_{s}(\mathrm{~g} / \mathrm{mg} \min )$ & 0.035 & 0.034 & 0.020 & 0.012 & 0.008 & 0.011 \\
\hline & $R^{2}$ & 0.99 & 0.99 & 0.99 & 0.99 & 0.99 & 0.99 \\
\hline \multirow{3}{*}{ Intraparticle diffusion } & $k_{\text {id }}\left(\mathrm{mg} / \mathrm{g} \min ^{1 / 2}\right)$ & 1.06 & 0.937 & 1.03 & 1.79 & 1.59 & 2.42 \\
\hline & $C\left(\mathrm{mg} \mathrm{g}^{-1}\right)$ & 44.98 & 47.07 & 47.94 & 22.87 & 26.81 & 26.80 \\
\hline & $R^{2}$ & 0.95 & 0.91 & 0.99 & 0.95 & 0.98 & 0.99 \\
\hline \multirow{3}{*}{ Bangham } & $k_{o}(\mathrm{~g})$ & 115.6 & 123.5 & 129.1 & 39.59 & 48.84 & 51.84 \\
\hline & $A$ & 0.07 & 0.08 & 0.09 & 0.17 & 0.14 & 0.17 \\
\hline & $R^{2}$ & 0.98 & 0.96 & 0.96 & 0.98 & 0.97 & 0.98 \\
\hline \multirow{3}{*}{ Elovich } & $a(\mathrm{mg} / \mathrm{g} \min )$ & $1.15 \times 10^{10}$ & $5.47 \times 10^{10}$ & $3.29 \times 10^{11}$ & $8.69 \times 10^{2}$ & $4.88 \times 10^{3}$ & $2.11 \times 10^{3}$ \\
\hline & $b\left(\mathrm{~g} \mathrm{mg}^{-1}\right)$ & 0.509 & 0.524 & 0.525 & 0.264 & 0.298 & 0.242 \\
\hline & $R^{2}$ & 0.98 & 0.96 & 0.96 & 0.98 & 0.96 & 0.99 \\
\hline
\end{tabular}

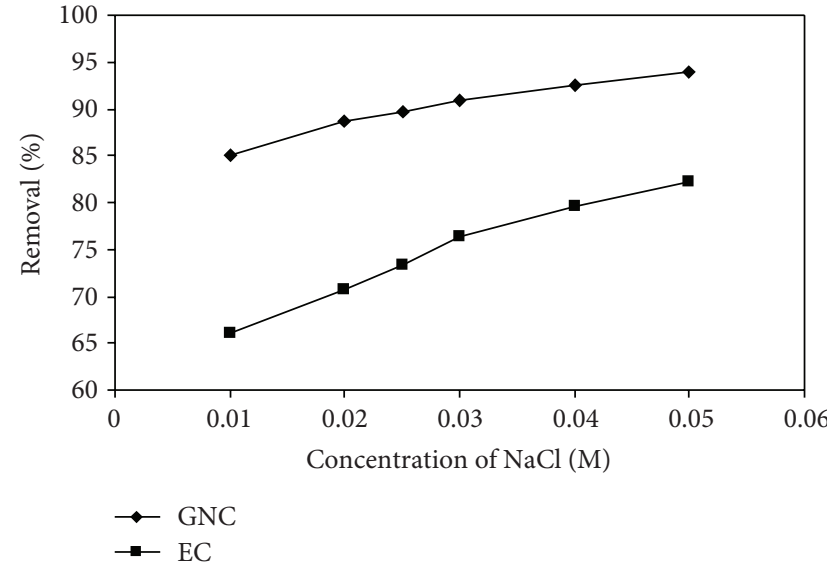

(a)

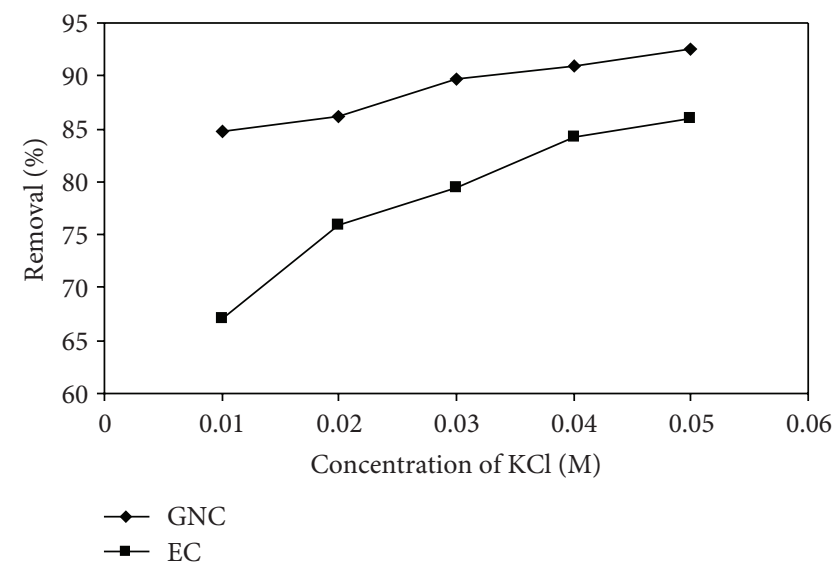

(b)

FIGURE 7: Effect of ionic strength on sorption of congo red by GNC and EC (sorbent dose $=1 \mathrm{~g} \mathrm{~L}^{-1}, \mathrm{Co}=65 \mathrm{mg} \mathrm{L}{ }^{-1}, \mathrm{pH}=7.0$ ).

boundary layer effect [37]. This is attributed to the instantaneous utilization of the most readily available adsorbing sites on the adsorbent surface. The values of $k_{\mathrm{id}}$ and $C$ obtained from the slope and intercept of linear plots are listed in Table 1.

3.10.3. Elovich Model. The most interesting model to describe the activated chemisorptions is Elovich equation [38]:

$$
q_{t}=\frac{1}{b} \ln (a b)+\frac{1}{b} \ln t
$$

where $a$ and $b$ are constants. The constant $a$ is considered as the initial sorption rate $(\mathrm{mg} /(\mathrm{g} \min ))$ and $b$ is related to the extent of surface coverage and activation energy for chemisorption $\left(\mathrm{g} \mathrm{mg}^{-1}\right)$ and $q_{t}\left(\mathrm{mg} \mathrm{g}^{-1}\right)$ is the amount of dye adsorbed at time $t$ ( $\mathrm{min})$. The values of $a$ and $b$ obtained from the linear plots of $q_{t}$ versus $\ln t$, are comprised in Table 1.

3.10.4. Bangham's Equation. Kinetic data were further used to know about the slow step occurring in the present adsorption system using Bangham's equation [39]:

$$
\log \log \left(\frac{C_{\mathrm{o}}}{C_{\mathrm{o}}}-q_{t} m\right)=\log \left(\frac{k_{\mathrm{o}} m}{2.303 V}\right)+\alpha \log t
$$

where $C_{o}$ is the initial concentration of dye in solution $\left(\mathrm{mg} \mathrm{L}^{-1}\right) . V$ is the volume of the solution $(\mathrm{mL}), m$ is 


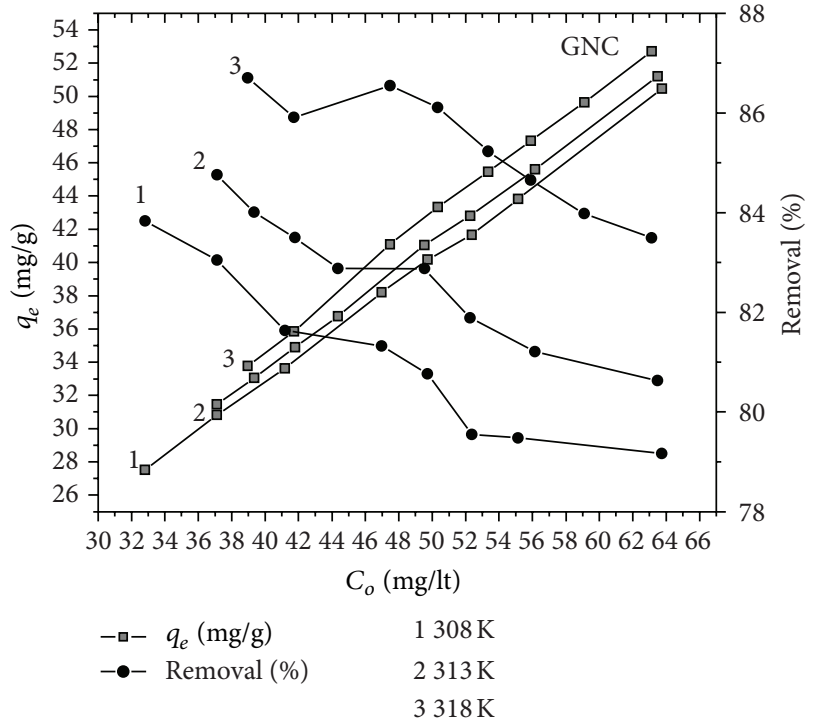

(a)

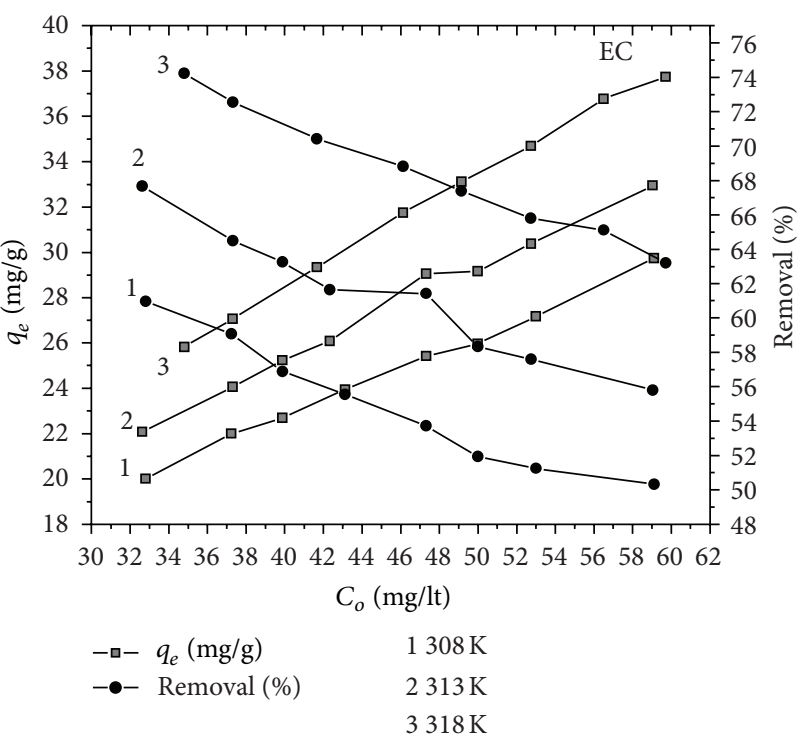

(b)

FIGURE 8: Effect of initial concentration of dye congo red on colour removal by GNC and EC. (sorbent dose $=1 \mathrm{gL}^{-1}, \mathrm{Co}=65 \mathrm{mg} \mathrm{L}-1, \mathrm{pH}=$ 7) at different temperatures.

the weight of adsorbent per liter of solution $\left(\mathrm{g} \mathrm{L}^{-1}\right), q_{t}$ $\left(\mathrm{mg} \mathrm{g}^{-1}\right)$ is amount of dye adsorbed at time $t$, and $\alpha(<1)$ and $k_{\mathrm{o}}$ are constants and are accommodated in Table 1. Linear plot $\left(\log \log \left(C_{\mathrm{o}} / C_{\mathrm{o}}-q_{t} m\right)\right.$ versus $\left.\log t\right)$ demonstrated that the diffusion of adsorbate into pores of adsorbents is not the only rate controlling step [40].

3.11. Adsorption Isotherm. To describe the equilibrium nature of adsorption various isotherm equations have been used such as Langmuir, Freundlich, Dubinin and Radushkevich, Temkin equations, and Genralized Isotherm.

3.11.1. Freundlich Isotherm. This isotherm is an empirical equation employed to describe heterogeneous system. Freundlich isotherm is also applied to plot the equilibrium data of the adsorption. The linear form of Freundlich equation can be expressed as [41]:

$$
\log \frac{x}{m}=\log K_{F}+\frac{1}{n} \log C_{e}
$$

where $x$ is the amount of dye adsorbed $(\mathrm{mg}), m$ is the weight of the adsorbent used $(\mathrm{g})$, and $C_{e}$ is the equilibrium concentration of the dye in solution $\left(\mathrm{mg} \mathrm{L}^{-1}\right) . K_{F}$ and $1 / n$ are Freundlich constant. $1 / n$ is heterogeneity factor and $K_{F}$ indicates the adsorption capacity. The value of $n>1$, reflecting the favorable adsorption. The values of $n$ and $K_{F}$ are calculated from the slopes and intercepts of the linear plots of $\log (x / m)$ versus $\log C_{e}$ and are given in Table 2. Adsorption capacity increases with increase in temperature.

3.11.2. Langmuir Isotherms. The Langmuir isotherm model is valid for monolayer adsorption onto a surface containing a finite number of identical sites. The linear form of Langmuir Isotherm is represented by the following equation:

$$
\frac{C_{e}}{q_{e}}=\frac{C_{e}}{C_{m}}+\frac{1}{K_{L} C_{m}}
$$

where $C_{e}$ is the concentration of dye solution $\left(\mathrm{mg} \mathrm{L}^{-1}\right)$ at equilibrium and $\mathrm{q}_{e}\left(\mathrm{mg} \mathrm{g}^{-1}\right)$ is the adsorption capacity at equilibrium. The constant $C_{m}$ signifies the adsorption capacity $\left(\mathrm{mg} \mathrm{g}^{-1}\right)$ when monolayer is complete and $K_{L}$ is related to the affinity of the binding sites. The values of $K_{L}$ and $C_{m}$ (monolayer concentration) were calculated from the intercept and slope of the plots $\left(C_{e} / q_{e}\right.$ versus $\left.C_{e}\right)$ are included in Table 2. Monolayer concentration increases with increase in temperature.

The essential feature of the Langmuir isotherm to identify the feasibility and favorability of the adsorption process can be expressed by a dimensionless constant called separation factor $\left(R_{L}\right)$ was adopted. The separation factor $\left(R_{L}\right)$ was calculated in each case using the following equation:

$$
R_{L}=\frac{1}{\left(1+K_{L} C_{\mathrm{o}}\right)},
$$

where $C_{\mathrm{o}}$ is the initial dye concentration $\left(\mathrm{mg} \mathrm{L}^{-1}\right)$. The value of $R_{L}$ lies between 0 and 1 for favorable adsorption, while $R_{L}>1$ represent unfavorable adsorption, and $R_{L}=1$ represent linear adsorption while the adsorption process is irreversible if $R_{L}=0$ [42]. The values of " $R_{L}$ " were found to be less than unity for the studied adsorbents and are contained in Table 4, states highly favorable adsorption for the dye congo red on studied biosorbents.

3.11.3. Temkin Isotherm. The Temkin isotherm equation suggests a linear decrease of sorption energy as the degree 
TABLE 2: Isotherm parameters for the removal of congo red by GNC and EC at different temperatures.

\begin{tabular}{|c|c|c|c|c|c|c|c|}
\hline \multirow{3}{*}{ Equations } & \multirow{3}{*}{ Parameters } & \multicolumn{6}{|c|}{ Adsorbents } \\
\hline & & \multicolumn{3}{|c|}{ GNC } & \multicolumn{3}{|c|}{ EC } \\
\hline & & $308 \mathrm{~K}$ & $313 \mathrm{~K}$ & $318 \mathrm{~K}$ & $308 \mathrm{~K}$ & $313 \mathrm{~K}$ & $318 \mathrm{~K}$ \\
\hline \multirow{3}{*}{ Freundlich } & $K_{F}(\mathrm{mg} / \mathrm{g})(\mathrm{L} / \mathrm{mg})^{1 / n}$ & 9.44 & 10.36 & 12.02 & 6.38 & 7.70 & 9.82 \\
\hline & $N$ & 1.56 & 1.58 & 1.57 & 2.23 & 2.25 & 2.28 \\
\hline & $R_{2}$ & 0.99 & 0.99 & 0.96 & 0.98 & 0.98 & 0.99 \\
\hline \multirow{3}{*}{ Langmuir } & $K_{L}\left(\mathrm{~L} \mathrm{mg}^{-1}\right)$ & 0.064 & 0.067 & 0.078 & 0.059 & 0.071 & 0.088 \\
\hline & $C_{m}\left(\mathrm{mg} \mathrm{g}^{-1}\right)$ & 106.38 & 112.35 & 117.64 & 45.24 & 49.75 & 56.81 \\
\hline & $R^{2}$ & 0.98 & 0.96 & 0.99 & 0.97 & 0.98 & 0.99 \\
\hline \multirow{3}{*}{ Dubinin Radushkevih } & $q_{\mathrm{s}}\left(\mathrm{mg} \mathrm{g}^{-1}\right)$ & 51.26 & 55.25 & 60.78 & 30.29 & 33.58 & 39.36 \\
\hline & $E\left(\mathrm{KJ} \mathrm{mol}^{-1}\right)$ & 0.380 & 0.381 & 0.412 & 0.223 & 0.250 & 0.294 \\
\hline & $R^{2}$ & 0.96 & 0.97 & 0.99 & 0.91 & 0.94 & 0.96 \\
\hline \multirow{3}{*}{ Temkin } & $K_{T}\left(\mathrm{~L} \mathrm{mg}^{-1}\right)$ & 0.574 & 0.584 & 0.676 & 0.475 & 0.571 & 0.705 \\
\hline & $B_{1}$ & 23.73 & 25.36 & 26.97 & 10.93 & 12.00 & 13.75 \\
\hline & $R^{2}$ & 0.98 & 0.99 & 0.99 & 0.98 & 0.98 & 0.99 \\
\hline \multirow{3}{*}{ Generalized } & $N$ & 0.97 & 0.99 & 1.00 & 0.98 & 0.98 & 0.99 \\
\hline & $K_{G}\left(\mathrm{mg} \mathrm{L}^{-1}\right)$ & 15.32 & 14.75 & 16.24 & 16.00 & 13.42 & 11.01 \\
\hline & $R^{2}$ & 0.98 & 0.99 & 0.99 & 0.96 & 0.98 & 0.99 \\
\hline
\end{tabular}

of completion of the sorptional centres of an adsorbent is increased. This model takes into account the presence of indirect adsorbate/adsorbent interactions and suggests that because of these interactions the heat of adsorption of all molecules in the layer would decrease linearly with coverage [43]. The Temkin isotherm has generally been applied in the following form:

$$
q_{e}=B_{1} \ln K_{T}+B_{1} \ln C_{e}
$$

The constant $K_{T}$ and $B_{1}$ can be calculated using a linear plot of $q_{e}$ versus $\ln C_{e} . K_{T}$ is the equilibrium binding constant $\left(\mathrm{L} \mathrm{mg}^{-1}\right)$ corresponding to maximum binding energy and the value increased with increase in temperature for both the adsorbents suggestive of the corresponding increase of maximum binding energy and constant $B_{1}$ is related to heat of adsorption. The values of the constants are presented in Table 2 .

3.11.4. Dubinin and Radushkevich (D-R) Isotherm. D-R isotherm is generally used to describe the sorption isotherms of single solute system. The $\mathrm{D}-\mathrm{R}$ isotherm, apart from being analogue of Langmuir isotherm, is more general than Langmuir isotherm as it rejects the homogenous surface or constant adsorption potential [44]. It is expressed as

$$
\ln q_{e}=\ln q_{s}-B \epsilon^{2}
$$

where $q_{e}$ is D-R constant and $\epsilon$ can be correlated as

$$
\epsilon=R T \ln \left(1+\frac{1}{C_{e}}\right),
$$

where $q_{s}$ is the maximum amount of adsorbate that can be adsorbed on adsorbent, $B$ is the constant related to energy, and $C_{e}$ is the equilibrium concentration $\left(\mathrm{mg} \mathrm{L}^{-1}\right) . R$ is Universal gas constant, $8.314 \mathrm{~J} \mathrm{~mol}^{-1} \mathrm{~K}^{-1}, T$ is the temperature
(K). The mean free energy $E$ of the adsorption per molecule of adsorbate can be calculated using the following equation:

$$
E=\frac{1}{(2 B)^{1 / 2}} \text {. }
$$

The calculated D-R constant are given in provided 2. It is clear that adsorption energy value is more for congo red on ground nut shells charcoal as compare to EC.

3.11.5. Generalized Isotherm. The Generalized Isotherm has been used in the following form [45]:

$$
\ln \left[\left(\frac{q_{\max }}{q_{e}}\right)-1\right]=\ln K_{G}-N \ln C_{e}
$$

where $K_{G}$ is the saturation constant $\left(\mathrm{mg} \mathrm{L}^{-1}\right), N$ is the cooperative binding constant, $q_{\max }$ is the maximum adsorption capacity of the adsorbent $\left(\mathrm{mg} \mathrm{g}^{-1}\right) \cdot q_{e}\left(\mathrm{mg} \mathrm{g}^{-1}\right)$, and $C_{e}$ $\left(\mathrm{mg} \mathrm{L}^{-1}\right)$ are the equilibrium dye concentrations in the solid and liquid phase, respectively. The values of $N$ and $K_{G}$ are calculated from the slope and intercept of the plots and these values are produced in Table 2.

3.12. Error Analysis. Due to the inherent bias resulting from linearization, five different error functions of nonlinear regression basin were employed in this study to find out the best-fit isotherm model to the experimental equilibrium data.

The Sum of the Squares of the Errors (SSE). This error function, $\mathrm{SSE}$, is given as

$$
\mathrm{SSE}=\sum_{i=1}^{n}\left(q_{e, \mathrm{calc}}-q_{e, \exp }\right)_{i}^{2} .
$$

Here, $q_{e, \text { cal }}$ and $q_{e \text {,exp }}$ are, respectively, the calculated and the experimental value of the equilibrium adsorbate solid 
TABLE 3: Isotherm error analysis for adsorption of congo red by GNC and EC at different temperatures.

\begin{tabular}{|c|c|c|c|c|c|c|c|c|c|c|c|c|}
\hline \multirow{2}{*}{ GNC } & \multicolumn{3}{|c|}{ SSE } & \multicolumn{3}{|c|}{ SAE } & \multicolumn{3}{|c|}{ ARE } & \multicolumn{3}{|c|}{ HYBRID } \\
\hline & & & & & & & & & & & & \\
\hline Temp. & $308 \mathrm{~K}$ & $313 \mathrm{~K}$ & $318 \mathrm{~K}$ & $308 \mathrm{~K}$ & $313 \mathrm{~K}$ & $318 \mathrm{~K}$ & $308 \mathrm{~K}$ & $313 \mathrm{~K}$ & $318 \mathrm{~K}$ & $308 \mathrm{~K}$ & $313 \mathrm{~K}$ & $318 \mathrm{~K}$ \\
\hline Langmuir & 7.11 & 3.21 & 8.79 & 6.07 & 4.70 & 6.51 & 1.94 & 1.49 & 1.98 & 0.06 & 0.48 & -1.44 \\
\hline Freundlich & 4.34 & 2.02 & 12.89 & 4.97 & 3.50 & 7.91 & 1.53 & 1.11 & 2.37 & -0.03 & -0.12 & -2.56 \\
\hline Temkin & 10.35 & 4.76 & 8.62 & 7.34 & 5.39 & 6.42 & 2.37 & 1.71 & 1.91 & 0.006 & 0.006 & -2.64 \\
\hline $\mathrm{D}-\mathrm{R}$ & 36.65 & 19.41 & 6.36 & 12.74 & 9.51 & 6.29 & 4.05 & 2.98 & 1.89 & 0.265 & 0.15 & 0.20 \\
\hline \multicolumn{13}{|l|}{ EC } \\
\hline Temp. & $308 \mathrm{~K}$ & $313 \mathrm{~K}$ & $318 \mathrm{~K}$ & $308 \mathrm{~K}$ & $313 \mathrm{~K}$ & $318 \mathrm{~K}$ & $308 \mathrm{~K}$ & $313 \mathrm{~K}$ & $318 \mathrm{~K}$ & $308 \mathrm{~K}$ & $313 \mathrm{~K}$ & $318 \mathrm{~K}$ \\
\hline Langmuir & 1.85 & 3.87 & 0.72 & 3.29 & 3.23 & 0.39 & 1.62 & 1.57 & 0.19 & 0.03 & 0.07 & -0.25 \\
\hline Freundlich & 1.34 & 2.53 & 0.45 & 2.83 & 3.52 & 1.42 & 1.38 & 1.67 & 0.56 & 0.01 & -6.43 & -24.64 \\
\hline Temkin & 1.80 & 4.59 & 31.15 & 3.17 & 4.95 & 15.23 & 1.56 & 2.42 & 6.79 & 1.44 & -16.23 & -46.59 \\
\hline $\mathrm{D}-\mathrm{R}$ & 4.92 & 12.33 & 6.97 & 4.57 & 8.42 & 5.81 & 2.24 & 4.00 & 2.55 & -32.25 & -37.30 & 9.53 \\
\hline
\end{tabular}

TABLE 4: Thermodynamic parameters and $R_{L}$ values for the adsorption of congo red on GNC and EC at different temperatures.

\begin{tabular}{lccccr}
\hline Adsorbents & Temp. $(\mathrm{K})$ & $R_{L}$ values & $-\Delta G\left(\mathrm{KJ} \mathrm{mol}^{-1}\right)$ & $\Delta H\left(\mathrm{KJ} \mathrm{mol}^{-1}\right)$ & $\Delta S\left(\mathrm{JK}^{-1} \mathrm{~mol}^{-1}\right)$ \\
\hline \multirow{3}{*}{ GNC } & 308 & 0.20 & 27.41 & & \\
& 313 & 0.19 & 27.97 & 16.06 & 0.98 \\
\hline \multirow{3}{*}{ EC } & 318 & 0.17 & 28.82 & & 141.0 \\
& 308 & 0.22 & 27.23 & 32.53 & 194.0 \\
\hline
\end{tabular}

concentration in the solid phase $\left(\mathrm{mg} \mathrm{g}^{-1}\right)$ and $n$ is the number of data points. This is the most commonly used error function [46].

The Sum of the Absolute Errors (SAE). SAE is given as

$$
\mathrm{SAE}=\sum_{i=1}^{n}\left(\left|q_{e, \mathrm{calc}}-q_{e, \exp }\right|\right)_{i}
$$

Isotherm parameters determined using the sum of the absolute errors (SAE) method provides a better fit as the magnitude of the errors increases, biasing the fit towards the high-concentration data [46].

The Average Relative Error ( $A R E)$. ARE is given as

$$
\mathrm{ARE}=\frac{100}{n} \sum_{i=1}^{n}\left|\frac{q_{e, \mathrm{calc}}-q_{e, \exp }}{q_{e, \exp }}\right|_{i}
$$

The average relative error (ARE) function attempts to minimize the fractional error distribution across the entire concentration range [47].

The Hybrid Fractional Error Function (HYBRID). HYBRID is given as

$$
\mathrm{HYBRID}=\frac{100}{n-p} \sum_{i=1}^{n}\left[\frac{q_{e, \mathrm{calc}}-q_{e, \exp }}{q_{e, \exp }}\right]_{i}
$$

This error function was developed [48] to improve the fit of the ARE method at low-concentration values. Instead of $n$ as used in ARE, the sum of the fractional errors is divided by $(n-p)$, where $p$ is the number of parameters in the isotherm equation.
Table 3 shows that Freundlich model best fits the removal of dye congo red by GNC and EC at $308 \mathrm{~K}, 313 \mathrm{~K}$, and $318 \mathrm{~K}$. Results also reveal that the error functions are less in case of $\mathrm{EC}$ as compare to GNC.

3.13. Thermodynamic Properties. The adsorption isotherm data obtained at different temperatures were used to calculate important thermodynamic parameters such as changes in Gibbs free energy $\Delta G$, enthalpy change $\Delta H$, and entropy change $\Delta S$. The Langmuir constant, $K_{L}\left(\mathrm{~L} \mathrm{~mole}^{-1}\right)$ was used to calculate changes in Gibbs free energy according to the following equations:

$$
\begin{aligned}
& \Delta G=-R T \ln K_{L}, \\
& \Delta G=\Delta H-T \Delta S .
\end{aligned}
$$

From (22), we get

$$
\ln K_{L}=-\frac{\Delta H}{R T}+\frac{\Delta S}{R} .
$$

The plot of $\ln K_{L}$ versus $1 / T$ was found to be linear and $\Delta H$ and $\Delta S$ values were calculated from the slope and intercept of the plot by linear regression method and are listed in Table 4. The positive values of $\Delta H$ for GNC and EC suggest that adsorption process is endothermic in nature and increase of temperature activates the adsorption sites. The positive value of $\Delta S$ indicates increase in the randomness in the system [49]. The negative values of $\Delta G$ indicate the feasibility and spontaneity of the adsorption process. The $\Delta G$ value becomes more negative with increasing temperature supports that $\mathrm{CR}$ adsorption on GNC and EC is favored with the increase in temperature. 


\section{Conclusion}

(i) The adsorption of dye CR was examined at different experimental conditions. The results corroborate that adsorption increases with increase in temperatures, adsorbent dose, ionic strength, and contact time.

(ii) The maximum removal of dye $\mathrm{CR}$ at $318 \mathrm{~K}$ was found to be 83 and $60 \%$ for GNC and EC, respectively.

(iii) Scanning electron microscope (SEM) study shows that the macro-pores on the surface of adsorbents are filled up by dye molecules after adsorption. It is also alluded in FTIR analysis that dye is loaded on the adsorbent surface.

(iv) Particle size of adsorbent materials was calculated from XRD studies and was found to be 42.4 and $13.4 \mathrm{~nm}$ at maximum intensity for EC and GNC, respectively.

(v) Kinetics study shows the adsorption reaction follows pseudo-second order kinetic model $\left(R^{2}=0.99\right)$. The equilibrium data were found to be well represented by Freundlich isotherm which shows that the surface is heterogeneous in nature. It is also strengthened by error analysis.

(vi) The maximum adsorption capacity increases with increase in temperature and was found to be 117.6 and $56.8 \mathrm{mg} \mathrm{g}^{-1}$ for GNC and EC, respectively at $318 \mathrm{~K}$.

(vii) The negative value of change in Gibb's free energy implied that the reaction is spontaneous in nature, and values are more negative with temperature intimating that adsorption is favored with increase in temperature for both the studied adsorbents.

(viii) Adsorption is favored at high temperature for both the studied adsorbents is also evident by the high values of various constants at high temperature, for example, Temkin constants $K_{T}$ (equilibrium binding constant), Freundlich constant, $K_{F}$ (adsorption capacity), Langmuir constant $K_{L}$ (affinity to binding sites), $C_{m}$ (monolayer concentration), and energy $E$ (D-R isotherm), which is also confirmed by the positive values of enthalpy change.

(ix) The $R_{L}$ values also approve that biosorbents GNC and EC can be used favorably for the adsorption of dye CR.

The present research work established that GNC and EC were excellent low-cost bioadsorbents for the removal of dye congo red. The kinetics and thermodynamic data can be further explored for the design of an adsorber for industrial effluents treatment.

\section{References}

[1] S. T. Ong, C. K. Lee, and Z. Zainal, "Removal of basic and reactive dyes using ethylenediamine modified rice hull," Bioresource Technology, vol. 98, no. 15, pp. 2792-2799, 2007.
[2] Y. S. Ho and C. C. Chiang, "Sorption studies of acid dye by mixed sorbents," Adsorption, vol. 7, no. 2, pp. 139-147, 2001.

[3] B. H. Hameed and M. I. El-Khaiary, "Equilibrium, kinetics and mechanism of malachite green adsorption on activated carbon prepared from bamboo by $\mathrm{K}_{2} \mathrm{CO}_{3}$ activation and subsequent gasification with $\mathrm{CO}_{2}$," Journal of Hazardous Materials, vol. 157, no. 2-3, pp. 344-351, 2008.

[4] V. K. Gupta, I. Ali, Suhas, and D. Mohan, "Equilibrium uptake and sorption dynamics for the removal of a basic dye (basic red) using low-cost adsorbents," Journal of Colloid and Interface Science, vol. 265, no. 2, pp. 257-264, 2003.

[5] H. Chen and J. Zhao, "Adsorption study for removal of Congo red anionic dye using organo-attapulgite," Adsorption, vol. 15, no. 4, pp. 381-389, 2009.

[6] I. D. Mall, V. C. Srivastava, N. K. Agarwal, and I. M. Mishra, "Removal of congo red from aqueous solution by bagasse fly ash and activated carbon: kinetic study and equilibrium isotherm analyses," Chemosphere, vol. 61, no. 4, pp. 492-501, 2005.

[7] I. D. Mall, V. C. Srivastava, N. K. Agarwal, and I. M. Mishra, "Adsorptive removal of malachite green dye from aqueous solution by bagasse fly ash and activated carbon-kinetic study and equilibrium isotherm analyses," Colloids and Surfaces A, vol. 264, no. 1-3, pp. 17-28, 2005.

[8] P. Janoš, H. Buchtová, and M. Rýznarová, “Sorption of dyes from aqueous solutions onto fly ash," Water Research, vol. 37, no. 20, pp. 4938-4944, 2003.

[9] E. Eren and B. Afsin, "Investigation of a basic dye adsorption from aqueous solution onto raw and pre-treated sepiolite surfaces," Dyes and Pigments, vol. 73, no. 2, pp. 162-167, 2007.

[10] M. H. Karaoğlu, M. Doğan, and M. Alkan, "Removal of reactive blue 221 by kaolinite from aqueous solutions," Industrial and Engineering Chemistry Research, vol. 49, no. 4, pp. 1534-1540, 2010.

[11] C. A. Başar, "Applicability of the various adsorption models of three dyes adsorption onto activated carbon prepared waste apricot," Journal of Hazardous Materials, vol. 135, no. 1-3, pp. 232-241, 2006.

[12] G. Crini, "Non-conventional low-cost adsorbents for dye removal: a review," Bioresource Technology, vol. 97, no. 9, pp. 1061-1085, 2006.

[13] Sumanjit and T. P. S. Walia, "Use of dairy sludge for the removal of some basic dyes," Journal of Environmental Engineering and Science, vol. 7, no. 5, pp. 433-438, 2008.

[14] M. Koroki, S. Saito, H. Hashimoto, T. Yamada, and M. Aoyama, "Removal of $\mathrm{Cr}(\mathrm{VI})$ from aqueous solutions by the culm of bamboo grass treated with concentrated sulfuric acid," Environmental Chemistry Letters, vol. 8, no. 1, pp. 59-61, 2010.

[15] Q. Sun and L. Yang, "The adsorption of basic dyes from aqueous solution on modified peat-resin particle," Water Research, vol. 37, no. 7, pp. 1535-1544, 2003.

[16] K. V. Kumar and K. Porkodi, "Batch adsorber design for different solution volume/adsorbent mass ratios using the experimental equilibrium data with fixed solution volume/adsorbent mass ratio of malachite green onto orange peel," Dyes and Pigments, vol. 74, no. 3, pp. 590-594, 2007.

[17] R. Gong, Y. Sun, J. Chen, H. Liu, and C. Yang, "Effect of chemical modification on dye adsorption capacity of peanut hull," Dyes and Pigments, vol. 67, no. 3, pp. 175-181, 2005.

[18] Sumanjit and N. Prasad, "Adsorption of dyes on Rice Husk Ash," Indian Journal of Chemistry-section A, vol. 40, no. 4, pp. 388-391, 2001. 
[19] Sumanjit, R. K. Mahajan, S. Rani, T. P. S. Walia, and R. Kaur, "Adsorptive removal of five acid dyes using various unconventional adsorbents," Journal of Surface Science and Technology, vol. 26, no. 1-2, pp. 77-93, 2010.

[20] J. W. Ma, H. Wang, F. Y. Wang, and Z. H. Huang, "Adsorption of 2,4-dichlorophenol from aqueous solution by a new low-cost adsorbent-activated bamboo charcoal," Separation Science and Technology, vol. 45, no. 16, pp. 2329-2336, 2010.

[21] S. Jain and R. V. Jayaram, "Adsorption of phenol and substituted chlorophenols from aqueous solution by activated carbon prepared from jackfruit (artocarpus heterophyllus) peel-kinetics and equilibrium studies," Separation Science and Technology, vol. 42, no. 9, pp. 2019-2032, 2007.

[22] P. Vijayalakshmi, V. S. S. Bala, K. V. Thiruvengadaravi, P. Panneerselvam, M. Palanichamy, and S. Sivanesan, "Removal of acid violet 17 from aqueous solutions by adsorption onto activated carbon prepared from pistachio nut shell," Separation Science and Technology, vol. 46, no. 1, pp. 155-163, 2011.

[23] Z. Belala, M. Jeguirim, M. Belhachemi, F. Addoun, and G. Trouvé, "Biosorption of copper from aqueous solutions by date stones and palm-trees waste," Environmental Chemistry Letters, vol. 9, no. 1, pp. 65-69, 2011.

[24] J. Rivera-Utrilla, I. Bautista-Toledo, M. A. Ferro-Garca, and C. Moreno-Castilla, "Activated carbon surface modifications by adsorption of bacteria and their effect on aqueous lead adsorption," Journal of Chemical Technology and Biotechnology, vol. 76, no. 12, pp. 1209-1215, 2001.

[25] B. D. Cullity, Elements of X-Ray Diffraction, Addison-Wesley Publishing Company, 1956.

[26] P. Prema, S. Thangapandian, M. Selvarani, S. Subharanjani, and C. Amutha, "Color removal efficiency of dyes using nanozerovalent iron treatment," Toxicological and Environmental Chemistry, vol. 93, no. 10, pp. 1908-1917, 2011.

[27] V. S. Mane, I. D. Mall, and V. C. Srivastava, "Use of bagasse fly ash as an adsorbent for the removal of brilliant green dye from aqueous solution," Dyes and Pigments, vol. 73, no. 3, pp. 269-278, 2007.

[28] I. D. Mall, V. C. Srivastava, G. V. A. Kumar, and I. M. Mishra, "Characterization and utilization of mesoporous fertilizer plant waste carbon for adsorptive removal of dyes from aqueous solution," Colloids and Surfaces A, vol. 278, no. 1-3, pp. 175-187, 2006.

[29] C. Namasivayam, N. Muniasamy, K. Gayatri, M. Rani, and $\mathrm{K}$. Ranganathan, "Removal of dyes from aqueous solutions by cellulosic waste orange peel," Bioresource Technology, vol. 57, no. 1, pp. 37-43, 1996.

[30] C. Namasivayam and D. Kavitha, "Removal of Congo Red from water by adsorption onto activated carbon prepared from coir pith, an agricultural solid waste," Dyes and Pigments, vol. 54, no. 1 , pp. 47-58, 2002.

[31] M. Doğan and M. Alkan, "Adsorption kinetics of methyl violet onto perlite," Chemosphere, vol. 50, no. 4, pp. 517-528, 2003.

[32] D. Karadag, E. Akgul, S. Tok, F. Erturk, M. A. Kaya, and M. Turan, "Basic and reactive dye removal using natural and modified zeolites," Journal of Chemical and Engineering Data, vol. 52, no. 6, pp. 2436-2441, 2007.

[33] S. Lagergren, "Zur theorie der sogenannten adsorption geloster stoffe," Kungliga Sevenska Vetenskapasakademiens. Handlingar, vol. 24, pp. 1-39, 1898.

[34] K. G. Bhattacharyya and S. S. Gupta, "Adsorption of Fe(III) from water by natural and acid activated clays: studies on equilibrium isotherm, kinetics and thermodynamics of interactions," Adsorption, vol. 12, no. 3, pp. 185-204, 2006.

[35] Y. S. Ho and G. McKay, "The kinetics of sorption of divalent metal ions onto sphagnum moss peat," Water Research, vol. 34, no. 3, pp. 735-742, 2000.

[36] M. J. Weber and J. Morris, "Kinetic of adsorption on carbon from solution," ASCE Journal Saint Engineering Division, vol. 89, pp. 31-59, 1963.

[37] N. Kannan and M. M. Sundaram, "Kinetics and mechanism of removal of methylene blue by adsorption on various carbons-a comparative study," Dyes and Pigments, vol. 51, no. 1, pp. 25-40, 2001.

[38] M. Özacar and I. A. Şengil, "A kinetic study of metal complex dye sorption onto pine sawdust," Process Biochemistry, vol. 40, no. 2, pp. 565-572, 2005.

[39] C. Aharoni, S. Sideman, and E. Hoffer, "Adsorption of phosphate ions by collodion-coated alumina," Journal of Chemical Technology and Biotechnology, vol. 29, no. 7, pp. 404-412, 1979.

[40] E. Tütem, R. Apak, and C. F. Ünal, "Adsorptive removal of chlorophenols from water by bituminous shale," Water Research, vol. 32, no. 8, pp. 2315-2324, 1998.

[41] E. I. Unuabonah, K. O. Adebowale, and F. A. Dawodu, "Equilibrium, kinetic and sorber design studies on the adsorption of Aniline blue dye by sodium tetraborate-modified Kaolinite clay adsorbent," Journal of Hazardous Materials, vol. 157, no. 2-3, pp. 397-409, 2008.

[42] G. Crini, "Kinetic and equilibrium studies on the removal of cationic dyes from aqueous solution by adsorption onto a cyclodextrin polymer," Dyes and Pigments, vol. 77, no. 2, pp. 415-426, 2008.

[43] G. Crini and H. N. Peindy, "Adsorption of C.I. Basic Blue 9 on cyclodextrin-based material containing carboxylic groups," Dyes and Pigments, vol. 70, no. 3, pp. 204-211, 2006.

[44] W. Zheng, X. M. Li, F. Wang, Q. Yang, P. Deng, and G. M. Zeng, "Adsorption removal of cadmium and copper from aqueous solution by areca-A food waste," Journal of Hazardous Materials, vol. 157, no. 2-3, pp. 490-495, 2008.

[45] F. Kargi and S. Ozmihci, "Biosorption performance of powdered activated sludge for removal of different dyestuffs," Enzyme and Microbial Technology, vol. 35, no. 2-3, pp. 267-271, 2004.

[46] R. K. Rajoriya, B. Prasad, I. M. Mishra, and K. L. Wasewar, "Adsorption of benzaldehyde on granular activated carbon: kinetics, equilibrium, and thermodynamic," Chemical and Biochemical Engineering Quarterly, vol. 21, no. 3, pp. 219-226, 2007.

[47] A. Kapoor and R. T. Yang, "Correlation of equilibrium adsorption data of condensible vapours on porous adsorbents," Gas Separation and Purification, vol. 3, no. 4, pp. 187-192, 1989.

[48] J. F. Porter, G. McKay, and K. H. Choy, "The prediction of sorption from a binary mixture of acidic dyes using single- and mixed-isotherm variants of the ideal adsorbed solute theory," Chemical Engineering Science, vol. 54, no. 24, pp. 5863-5885, 1999.

[49] K. Vijayaraghavan and Y. S. Yun, "Biosorption of C.I. Reactive Black 5 from aqueous solution using acid-treated biomass of brown seaweed Laminaria sp.," Dyes and Pigments, vol. 76, no. 3, pp. 726-732, 2008. 

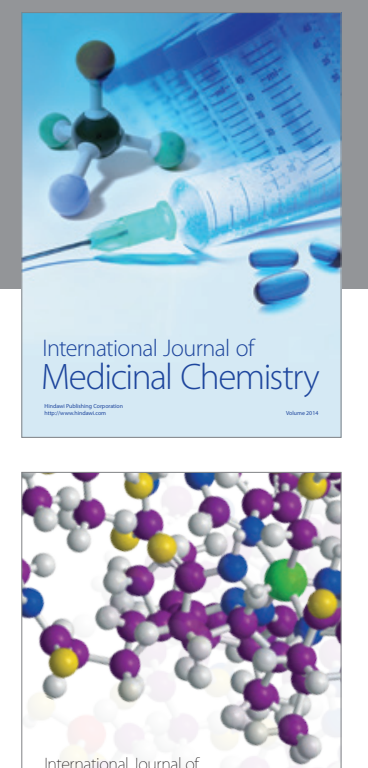

\section{Carbohydrate} Chemistry

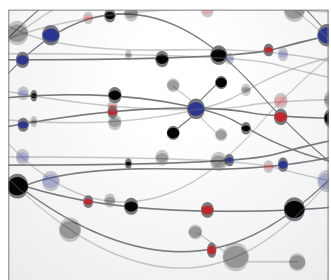

The Scientific World Journal
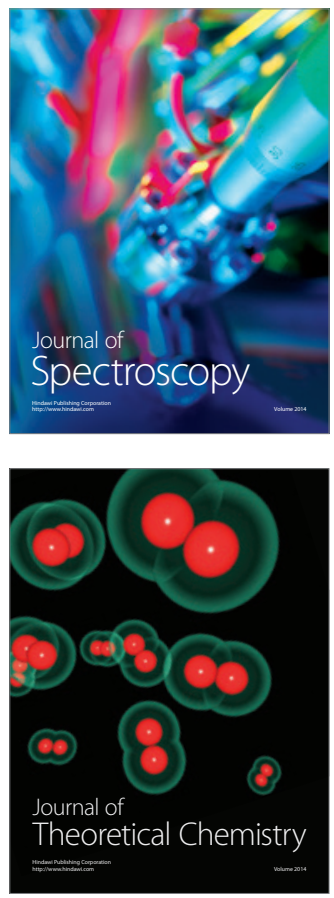
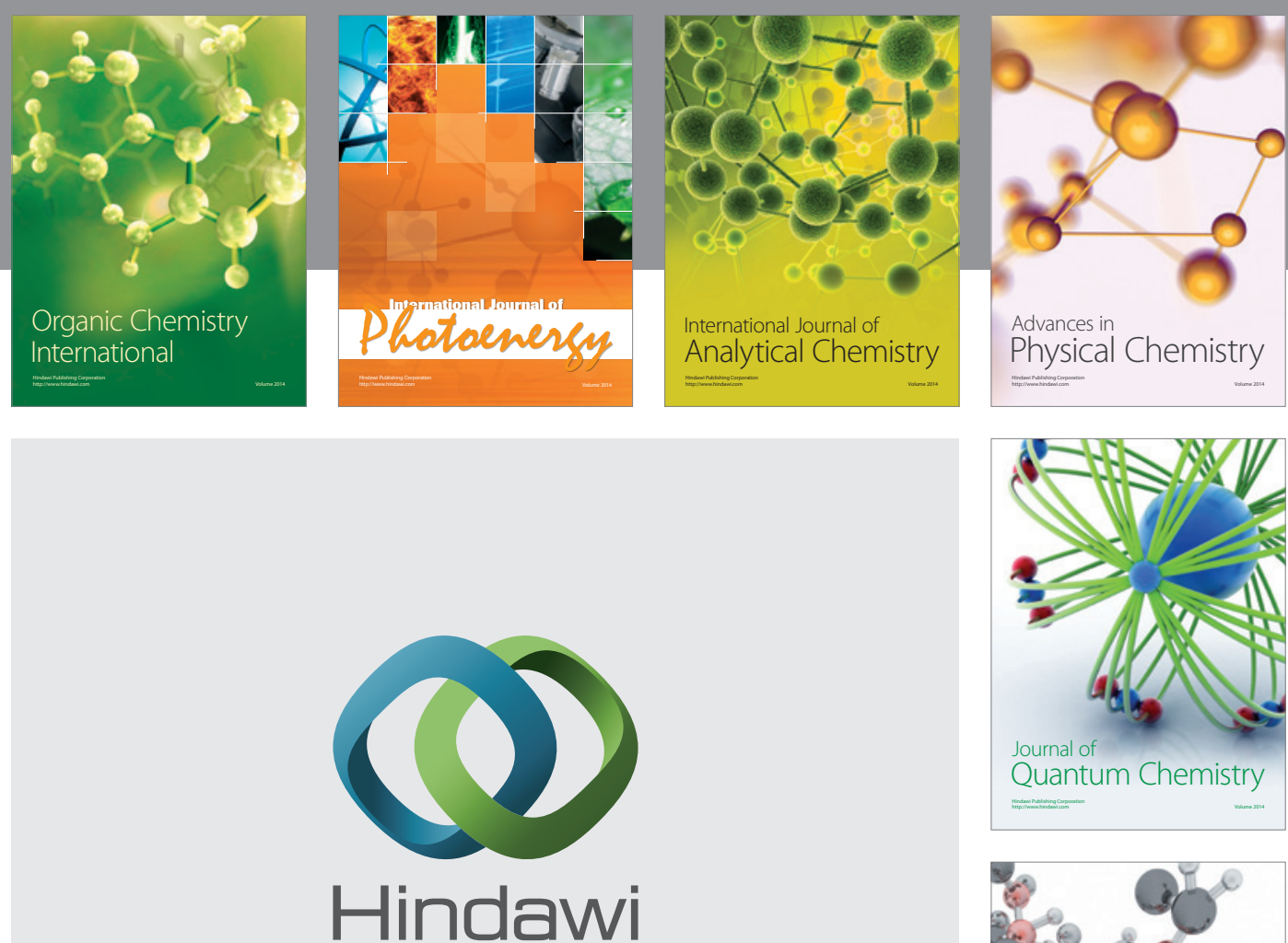

Submit your manuscripts at

http://www.hindawi.com

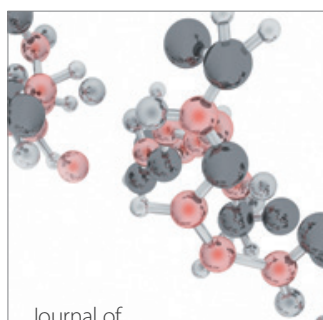

Analytical Methods

in Chemistry

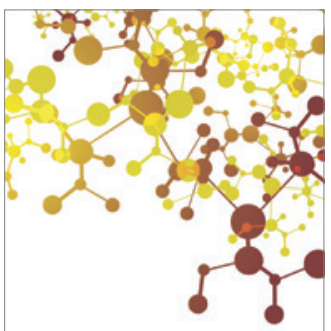

Journal of

Applied Chemistry

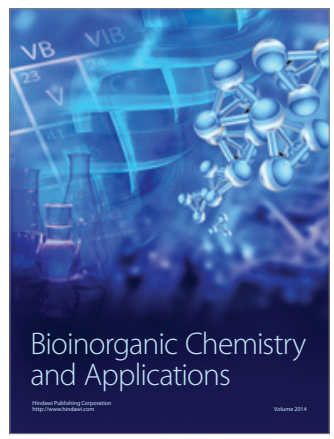

Inorganic Chemistry
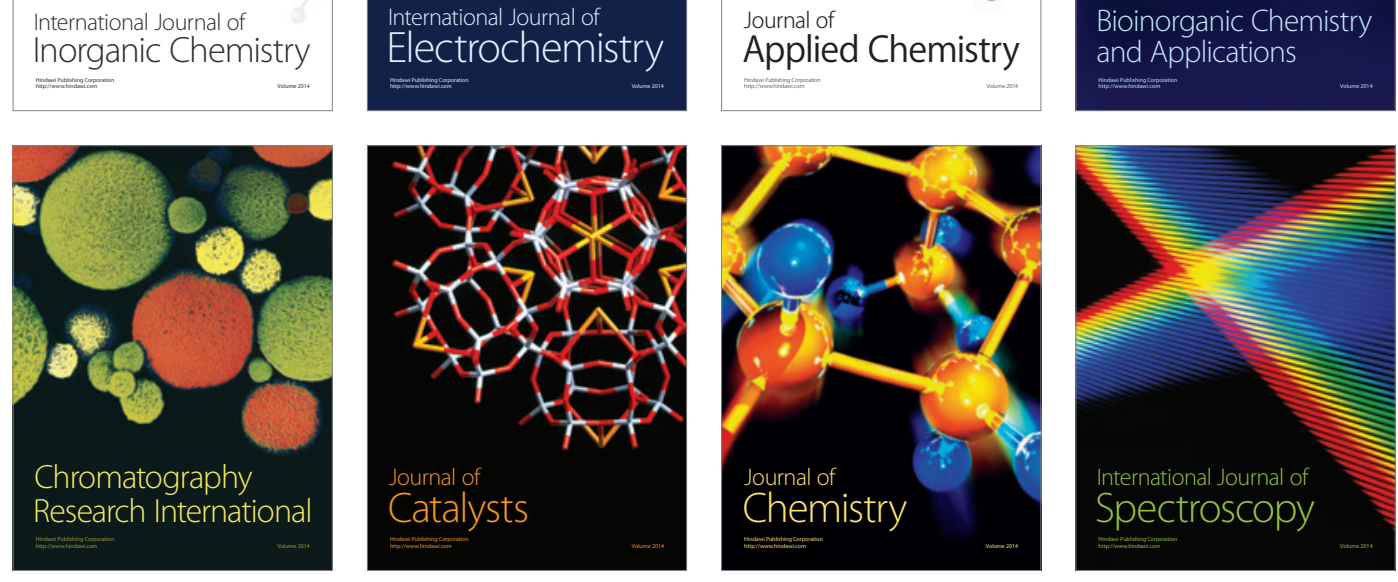